\title{
COMPARATIVE ANALYSIS OF ETFS AND INDEX FUNDS
}

\section{ELKA NIKHITHA REDDY \& N. SUBRAHMANYAM}

Research Scholar, KL Business School, KL University, Guntur, India

Professor, KL Business School, KL University, Guntur, India

ABSTRACT
Exchange Traded Funds (ETFs) and Index Funds both are innovative products. ETFs are baskets of securities
that are traded on the stock exchange. ETF bears the twin facets of a stock and a mutual fund whereas Index
Funds are mutual funds which replicate the overall performance of the large market index but can be bought or
redeemed solely at the end of the day at NA V. The proposed study aims to cover the overall performance
assessment of IndianETF's and index funds which track the identical benchmark. Five different Exchange
traded funds alongside with ten distinct Index funds are regarded in the study. The learn about is primarily
based on secondary data and covers five years i.e. from 2015-19 to consider the relative performance of selected
ETFs and Index Funds. The parameters used for evaluating the performance are Return, Risk, Sharpe Ratio,
Beta, and Jensen's Alpha. This study will enable to recognize the difference in the performance of two
significant similar passive investmentstrategies.
KEYWORDS: ETFs, Index Funds, Return, Risk, Sharpe Ratio, Beta, and Jensen's Alpha

Received: Jun 10, 2020; Accepted: Jun 30, 2020; Published: Aug 04, 2020; Paper Id.: IJMPERDJUN2020610

\section{INTRODUCTION}

Exchange traded funds are more popular in the global financial markets. In India, the growth of ETFs is gradually increasing year by year. ETFs are the best innovation in the Financial Markets. The goal of both the ETF and Index funds is to provide a way for the investors to own a well-diversified indexed portfolio in large quantities of stock at a lowcost.

An ETF is an investment company or a mutual fund whose shares are traded intraday on stock exchanges the same as other stocks with the market-implied prices.

ETFs are a basket of securities that hold assets such as stocks, bonds, or commodities and trade close to their net asset value (NAV) throughout the day. ETFs track a specific index or particular sector of the industry. ETFs have the positive aspects of both open-ended and closed-ended Mutual funds. Unlike ordinary open-ended mutual funds, ETFs can be bought and sold all through the trading day like the other publicly-traded company stocks. Whereas Mutual funds can be accessed solely at the end of the day.Exchange-traded funds (ETFs), which grant the flexibility of a stock and safety of a fund, are catching on success with Indian investors. ETFs, which make investments in stocks comprising an index, traded on exchanges.

Financial planners are more and more recommending ETFs to take a role who have long-term goals and need to make investments in equity besides taking an immoderate quantity of risk. This is reflected in average assets under management in the retail ETF category, which has risen from Rs fifty-nine crores in March 2009 to Rs 394 crores in March 2012 and ultimately stood 19,224.82 crores in 18th May 2016 [1]. 
An open-end fund may be a sort of mutual fund with a portfolio constructed to match or track the components of a market index. It is a passive type of investment that has been successful in outperforming most actively managed mutual funds. Index funds are often traded only at the top of the day at their Net Asset Value. It includes tracking an index say, for instance, the Sensex or the Nifty, and builds a portfolio with equivalent stocks within equal proportions due to the fact of the index. The Fund makes no effort to beat the index and actually, it merely tries to earn an equivalent return.

Exchange Traded Funds are originated in 1993 in the U.S. The first ETF to be listed as Standard and Poor's Depository Receipts (SPDRs). Morgan Stanley commenced the 2d ETF with the introduction of World Equity Benchmark Shares (WEBS). After the initial success of ETFs, brokerage companies and stock exchanges have launched various ETFs to track distinctive indices. By the late nineties, 30 US ETFs were representing a $\$ 33$ billion net asset value. Whereas, ETFs had been delivered in India in 2001 with the launch of the Nifty Benchmark Exchange Traded Scheme intended to tune S\&P CNX Nifty which allowed investors to gain a diversified portfolio with one single decision. Even after a decade, i.e. In April 2010 there had been completely 19 ETFs traded in the Indian market with the trading quantity of Rs.505 crore. Within a year that is by means of October 2011 differ of ETFs extensively accelerated to 30 with the trading quantity of Rs. 1962 crore and as of December 2015 there have been fifty-three ETFs trading in the market with the trading value of Rs. 2116.84 crore [2]. ETFs have several benefits over mutual funds, such as lower expense ratios, trading flexibility, tax efficiency, transparency, and publicity to divert asset classes [2].

ETFs and Index funds have been in existence in existence for more than a decade now however have now not gained the recognition that traditional mutual funds enjoy. Limited buyers are aware of the thought of Index Fund and Exchange Traded Funds. Relatively little is regarded about them. Thus, in this study efforts have been made to investigate the performance of ETFs compared to that of Index Funds in Indian context as it would enable us to know the difference in the performance of two very similar passive investment strategies. The study will further add to the literatureavailable [2].

\section{REVIEW OF LITERATURE}

Dr(MRS) Prashanth Athma, Mrs.B. Mamatha (2017): Identified the performance of ETFs in India and the progress of ETFs in India. It is identified that the growth of ETFs in terms of no of funds and NAV has increased. In this paper, he considered 38 schemes, out of 38 schemes 2 schemes were riskier (B>1.0) majority ranging between 0.006 and 0.77 . Out of 38 schemes, 17 ETFs identified positive Sharpe ratio and justified for the risk taken for earning a higher return. The performance of these 17 ETFs shows a higher return for higher risk [3].

Binu C Kurian (2014): Evaluated the overall performance of Exchange Traded Funds listed in NSE and analyzed the tracking ability of ETFs with their respective benchmark indexes. It is identified that all the ETFs have outperformed the market index in terms of annualized returns. ETFs are having more risk exposure which can be compensated by betterannualized returns. ETFs managed to givelesser negative returns when compared to the benchmark for the same period. The average tracking error also is sluggish which is reflects its close movement with regards to the benchmark index [4].

Narend (2014):Examined the overall performance of exchange-traded funds and index funds with the help of tracking error, active returns, and Jensen's alpha from the period of their inception up to July 2013. The analysis revealed that that tracking error was higher for ETFs when compared to index mutual funds. It was also found that both index funds and ETFs have not been able to grant extra returns over the market. In comparison to ETFs, index funds have outperformed in terms of tracking error and Jensen's alpha whereas in terms of active return ETFs have performed better [5]. 
Gerasimos G. Rompotis* KPMG Greece (2011): Examined the performance of Etf and index funds and the risk and expenses of Etf and index funds. The data utilized in this study concerns the ALPHA ETF FTSE ATHEX 20 and 4 open-ended mutual funds [6]. Calculated the average daily percentage return and risk of the examined Greek ETF and its corresponding mutual funds and also the tracking index [6]. The study reveals a major advantage of ETFs in terms of annual expenses, even if ETFs bear costs prices and commissions paid to brokerage companies. Concerning performance, Etf has displayed poor returns than mutual funds. The systematic risk of the ETF is lower than the respective risk [6].

\section{RESEARCH GAP}

Within the extant literature, the performance of ETFs has been compared with other ETFs. However, the overall performance of ETFs and Index funds has no longer been compared. This study examines the performance evaluation of Exchange Traded Funds and Index funds with reference to their underlying indices.

\section{NEED FOR THE STUDY}

The amazing growth of exchange traded funds in India has attracted the interest of Indian researchers and institutional investors. Severalempirical studies have been conducted to examine the growth, competition, and performance of exchange traded funds in India. There has been severe competition among a wide variety avenue of investment and the Exchange Traded Funds is no exception and the opposition would intensify in the coming years as it passed off in distinct investment avenues. Hence, it is suitable to focus our interest as to how the exchange traded funds would emerge in the coming few years and to verify how they continue to exist. Therefore, this study aims at making a performance evaluation of ETFs visà-vis Index funds to understand the barriers to the expansion of the ETFs in India.

\section{OBJECTIVES OF THE STUDY}

The Objectives of the Study are

- To present the growth of Exchange Traded Funds in India and

- To evaluate the performance of Exchange TradedFunds.

\section{DATA SOURCE \& METHODOLOGY}

The study is based on secondary data. Data is collected from websites of the National Stock Exchange and BSE. Consider 5 ETFs and 10 index funds as the selected sample for evaluation of the performance of ETFs and index funds. The performance of ETFs and index funds were analyzed by their annualized returns.

Annualized return $=$ average daily return $*$ no. of trading days

Average daily return $=$ sum of daily return $/$ No. of Observations

Data used is entirely secondary and is extracted from articles, newspapers, and websites of various asset management companies. Parameters used for evaluating the performance are Annual Returns, Risk, Sharpe Ratio, Beta, and Alpha.

\section{DISCUSSIONS}

\subsection{Growth of ETF's in India}

Since 2015, the ETF has become more diverse.Assets under Management for ETFs has developed approx. 13,800 crores to 1,41,500 crores from December 2014 to May 2019. 


\subsection{Choices / Factors Assumed An Urgent Job In Empowering This Colossal Development In Etfs:}

- In March 2014, the ETF endeavor got a broad improve when the Indian Government chose to upgrade cash with the guide of stripping their offer in open segment endeavors by methods for ETFs

- In August 2015, the Employees' Provident Fund Organization presented that it might take decency exposure exclusively by the method of ETFs. On account of this, an immense piece of cash has continuously come into ETFs in current years, and this is habitually just set to stretch every year as more individuals add to their PF/PPF account.

- The Government had ordered that Retirement and superannuation finances need to decent footing at least fifty of yearly growth in Equity markets. This has helped the general development of ETFs in India.

- By the underperformance of dynamic shared assets in 2018, there has been a reestablished enthusiasm inside the dynamic versus detached financial specialists moving to ease inactive other options.

- Growing speculator consideration and instruction: By the constant endeavors of SEBI, AMCs, financiers are prescribing ETFs to new financial specialists rather than single stocks.

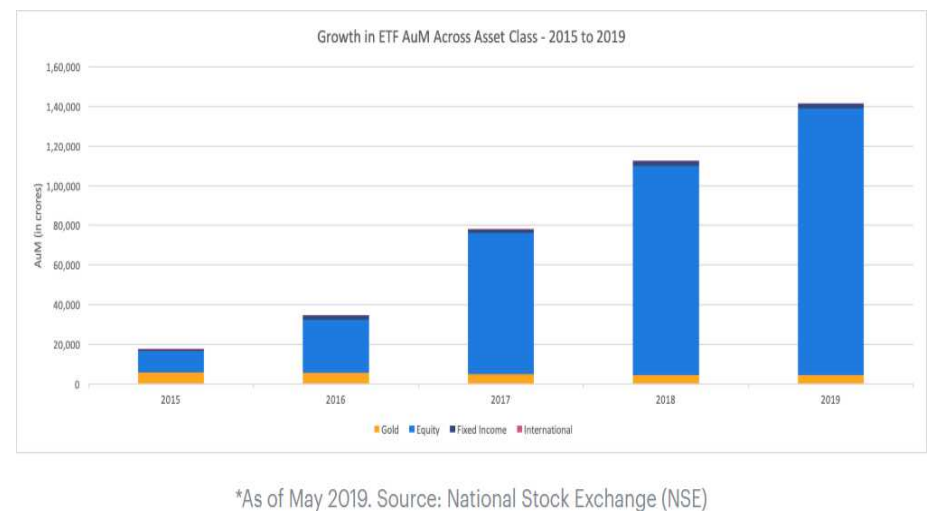

Figure 1

\section{CHARACTERISTICS OF ETFS AND INDEX FUNDS}

Exchange Traded Funds track indices to be popular in India. The characteristics of ETFs are explained in this study are given in Table 1.

This study considered 5 ETFs.The minimum investment required for the Kotak Nifty, Kotak Sensex, ICICI Prudential Nifty ETF, and SBI ETF Nifty is 10000 and for BHARAT 22 ETF is 5000. The Expense Ratio for Kotak Nifty and Kotak Sensex is 0.14 and 0.28. The Expense Ratio is minimum for BHARAT 22 ETF and ICICI Prudential Fund is 0.01 and 0 .

Table 1 shows that Nifty, Kotak Sensex, ICICI Prudential Nifty ETF, and SBI ETF Nifty is 10000 and for BHARAT 22 ETF is 5000. The Expense Ratio for Kotak Nifty and Kotak Sensex is 0.14 and 0.28. The Expense Ratio is minimum for BHARAT 22 ETF and ICICI Prudential Fund is 0.01 and 0.

"Index Funds are passively managed funds that are designed to replicate the underlying index that they track. Index Funds hold their stocks in the same proportion as that of the underlying index". Index Funds are very popular worldwide and even in India, index funds have found favor with the investing fraternity. The characteristics of the index funds examined in the research are given in Table 2. 
Table 2 suggests that most of the index funds used in our learn about have an exit load of less than $1 \%$ for their schemes and the minimal investment required is INR 5000.

UTI Index fund, ICICI prudential Index Fund, HDFC Index Fund are some of the largest Index Funds. ICICI Prudential Index Fund has the lowest exit load at $0.08 \%$, while the LIC MF Index fund has the highest exit load of $1 \%$.

Table 1: Characteristics of Exchange Traded Funds

\begin{tabular}{|c|c|c|c|c|c|c|c|}
\hline SI.No & ETF's & $\begin{array}{c}\text { Underlying } \\
\text { Index }\end{array}$ & $\begin{array}{c}\text { Listed } \\
\text { on }\end{array}$ & $\begin{array}{c}\text { Launch } \\
\text { Date }\end{array}$ & $\begin{array}{c}\text { AUM as on } \\
\text { 2020(CRORE) }\end{array}$ & $\begin{array}{c}\text { Expense } \\
\text { Ratio(\%) }\end{array}$ & $\begin{array}{c}\text { Minimum } \\
\text { Investment }\end{array}$ \\
\hline 1 & $\begin{array}{c}\text { Kotak Nifty } \\
\text { ETF }\end{array}$ & $\begin{array}{c}\text { Nifty 50 } \\
\text { Index }\end{array}$ & NSE & $\begin{array}{c}02- \\
\text { Feb-10 }\end{array}$ & 987.64 & 0.14 & 10000 \\
\hline 2 & $\begin{array}{c}\text { Kotak } \\
\text { Sensex ETF }\end{array}$ & SENSEX & BSE & $\begin{array}{c}06- \\
\text { Jun-08 }\end{array}$ & 12.71 & 0.28 & 10000 \\
\hline & $\begin{array}{c}\text { ICICl } \\
\text { prudential } \\
\text { Nifty ETF }\end{array}$ & $\begin{array}{c}\text { Nifty 50 } \\
\text { Index }\end{array}$ & NSE & $\begin{array}{c}20- \\
\text { Mar- } \\
13\end{array}$ & 1372.62 & 0 & 10000 \\
\hline 4 & $\begin{array}{c}\text { SBI ETF } \\
\text { Nifty }\end{array}$ & $\begin{array}{c}\text { Nifty 50 } \\
\text { Index }\end{array}$ & NSE & $\begin{array}{c}23-J u l- \\
15\end{array}$ & 64463.43 & 0.07 & 10000 \\
\hline 5 & $\begin{array}{c}\text { BHARAT } \\
22 \text { ETF }\end{array}$ & $\begin{array}{c}\text { S\&P BSE } \\
\text { BHARAT } \\
22 \text { index }\end{array}$ & NSE & $\begin{array}{c}28- \\
\text { Nov-17 }\end{array}$ & 6077.1 & 0.01 & 5000 \\
\hline
\end{tabular}

Source: Value Research.

Table 2: Characteristics of Index Funds

\begin{tabular}{|c|c|c|c|c|c|c|c|}
\hline Sl. No & Index Funds & $\begin{array}{c}\text { Underlying } \\
\text { Index }\end{array}$ & Launch Date & $\begin{array}{l}\text { AUM As On } \\
2020 \text { (Crore) }\end{array}$ & $\begin{array}{l}\text { Expense } \\
\text { Ratio(\%) } \\
\end{array}$ & $\begin{array}{l}\text { Minimu m } \\
\text { Investment }\end{array}$ & $\begin{array}{l}\text { Fund } \\
\text { Type }\end{array}$ \\
\hline 1 & UTI Nifty Index Fund(G) & Nifty & 06-Mar-00 & 1856 & 0.17 & 5000 & Open \\
\hline 2 & HDFC Index Fund-Nifty 50 Plan(G) & Nifty & 17-Jul-02 & 500 & 0.3 & 5000 & Open \\
\hline 3 & IDFC Nifty Fund(G) & Nifty & $30-A p r-10$ & 181.44 & 0.42 & 5000 & Open \\
\hline 4 & $\begin{array}{l}\text { ICICI Prudential Nifty Index } \\
\text { Fund(G) }\end{array}$ & Nifty & 26-Feb-02 & 565.41 & 0.45 & 5000 & Open \\
\hline 5 & TATA Nifty Index Fund Plan(G) & Nifty & $25-F e b-03$ & 24.46 & 0.45 & 5000 & Open \\
\hline 6 & HDFC Index Fund- Sensex $(\mathrm{G})$ & Sensex & $17-07-2002$ & 803.31 & 0.3 & 5000 & Open \\
\hline 7 & $\begin{array}{l}\text { TATA Nifty Index Fund Sensex } \\
\text { Plan(G) }\end{array}$ & Sensex & $25-02-2003$ & 14.89 & 0.46 & 5000 & Open \\
\hline 8 & $\begin{array}{l}\text { ICICI Prudential Sensex Index } \\
\text { Fund }(G)\end{array}$ & Sensex & $10-01-2003$ & 25.11 & 0.08 & 5000 & Open \\
\hline 9 & LIC MF Index Fund Sensex Plan(G) & Sensex & $05-12-2002$ & 20.73 & 1.06 & 5000 & Open \\
\hline 10 & $\begin{array}{l}\text { NIPPON India Index Fund-Sensex } \\
\text { Plan(G) }\end{array}$ & Sensex & $01-10-2010$ & 47.61 & 0.61 & 5000 & Open \\
\hline
\end{tabular}

\section{RETURNS OF ETFS AND INDEX FUNDS IN INDIA}

ETFs have been widely gaining attraction of investors as they provide the twin feature of stock and mutual funds. They provide investors with extensive publicity to the stock markets in distinctive countries and specific sectors, with relative ease, on a real-time basis that too at a low cost.

The Table below gives details relating to the annual returns of the ETFs and Index Funds during the period 2015 to 2019.

As per Table 3, the annual return of all the four Index Fund reveals that in 2019 UTI Nifty Index Fund provided the highest return of $10.64 \%$. Whereas, HDFC Index Fund Nifty Plan and Franklin India Index Nifty Plan is $9.66 \%$. In the year 2015, it was observed that index funds have performed very low. 
As per Table 4, In 2019 Reliance Nifty BeES provided the highest return of $12.78 \%$. Whereas, Kotak Nifty ETF has outperformed other funds in the year 2016. Aditya Birla Sun Life ETF provided low returns when compared to other funds.

Through, Comparative analysis it was observed that all the 8 funds are tracking Nifty 50 but still are providing different returns. In all the five years ETFs have provided the highest return.

In 2016, Kotak NIFTY ETF provided the highest return of $2.22 \%$. In 2017, ICICI Prudential Nifty ETF provided the highest return of $2.78 \%$. In 2018, Kotak Nifty Nifty ETF provided with the highest return of $10.24 \%$. In 2018 and 2019 Reliance Nifty BeES was outperformed with $12.78 \%$. In totality, it was observed that although Index Funds and ETFs are tracking the same index still ETFs are performing better than Indexfunds.

Table 3: Annual Returns of Index Funds (Figures in \%)

\begin{tabular}{|c|c|c|c|c|c|c|}
\hline S.No & Name of the Fund & 2015 & 2016 & 2017 & 2018 & 2019 \\
\hline & & & & & & \\
1 & Franklin India Index Nifty Plan & -3.58 & 2.67 & 0.14 & 7.44 & 9.66 \\
\hline & & & & & & \\
2 & HDFC Index Fund Nifty Plan & -3.09 & 2.01 & 2.07 & 3.87 & 7.94 \\
\hline & & & & & & \\
3 & IDBI Nifty Index Funds & -4.44 & 2.15 & 0.87 & 9.07 & 7.19 \\
\hline & & & & & & \\
4 & UTI Nifty Index Funds & -3.35 & 2.14 & 0.88 & 8.14 & 10.64 \\
\hline
\end{tabular}

Source: Value Research.

Table 4: Annual Returns of Exchange Traded Funds (Figures in \%)

\begin{tabular}{|c|c|c|c|c|c|c|}
\hline S.No & Name of the Fund & 2015 & 2016 & 2017 & 2018 & 2019 \\
\hline & & & & & & \\
\hline 1 & Kotak Nifty ETF & -2.91 & 2.22 & 2.62 & 10.24 & 10.64 \\
\hline 2 & Aditya Birla Sun Life ETF & -2.5 & 2.21 & 0.36 & 9.36 & 10.42 \\
\hline 3 & ICICI Prudential Nifty iWIN ETF & -2.96 & 1.53 & 2.78 & 9.2 & 10.18 \\
\hline & & & & & & \\
4 & Reliance ETF Nifty BeES & -3.2 & 2.07 & 2.43 & 10.04 & 12.78 \\
\hline
\end{tabular}

Source: Value Research.

\subsection{Risk Analysis of Exchange Traded Funds and Index Funds}

The variability of return is called Risk and it is measured with the help of standard deviation and Beta.

The below Table gives details relating to Alpha, Beta, Sharpe Ratio, Standard deviation. 
Table 5: Risk Analysis of ETFs and Index Funds

\begin{tabular}{|c|c|c|c|c|}
\hline Exchange Traded Funds & Alpha(\%) & Beta & Sharpe & SD \\
\hline KOTAK Nifty ETF & 0.76 & 1 & 0.32 & 12.88 \\
\hline KOTAK Sensex ETF & 2.41 & 1 & 0.44 & 13.43 \\
\hline ICICI Prudential Nifty ETF & 0.81 & 1 & 0.32 & 12.88 \\
\hline SBI ETF Nifty & 0.87 & 1 & 0.33 & 12.91 \\
\hline BHARAT 22 ETF & 0.53 & 0.98 & 0.15 & 12.12 \\
\hline Index Funds Tracking CNX Nifty \\
\hline UTI Nifty Index Fund(G) & 0.61 & 0.99 & 0.31 & 12.84 \\
\hline HDFC Index Fund-Nifty 50 Plan(G) & 0.48 & 0.99 & 0.3 & 12.86 \\
\hline IDFC Nifty Fund(G) & 0.54 & 0.99 & 0.3 & 12.74 \\
\hline ICICI Prudential Nifty Index Fund(G) & 0.66 & 0.99 & 0.26 & 12.85 \\
\hline TATA Nifty Index Fund Plan(G) & 0.29 & 0.99 & 0.28 & 12.77 \\
\hline Index Funds Tracking S \& P BSE Sensex & \\
\hline HDFC Index Fund-Sensex(G) & 0.98 & 0.98 & 0.43 & 12.87 \\
\hline TATA Nifty Index Fund Sensex Plan(G) & 0.97 & 0.97 & 0.42 & 12.7 \\
\hline ICICI Prudential Sensex Index Fund(G) & 0.99 & 0.99 & 0.33 & 12.9 \\
\hline LIC MF Index Fund Sensex Plan(G) & 0.98 & 0.98 & 0.36 & 12.83 \\
\hline NIPPON India Index Fund Sensex Plan(G) & 0.98 & 0.98 & 0.38 & 12.81 \\
\hline
\end{tabular}

\section{FINDINGS}

\subsection{Standard Deviation:}

Standard deviation is an especially splendid tool in investing and trading techniques because it helps to measure market and security volatility.

It is found that among the ETFs, Kotak Sensex ETF has the very best risk i.e. $13.43 \%$ whereas just in case of Index Funds, ICICI Prudential SENSEX INDEX FUND(G) has the highest risk of $12.9 \%$.

The standard deviations of the ETFs are above the Index Funds. It means the deviation of expected return is more in ETFs than Index Funds. ETFs are riskier compared to Index. As a result, ETF's returns are higher when compared to Index Funds.

\subsection{Sharpe Ratio}

It indicates the return to variability. Higher the ratio higher would be the overall performance of the fund in phrases of the returns for the risk taken.Investors take risks commensurate with the return earned. Higher the Risk, Higher the return and lower the risk, decrease the return.

It's found that each one the ETFs and Index Funds are showing a positive Sharpe ratio in comparison to Index Funds, ETFs have the higher ratio. Consistent with the Sharpe ratio, ETFs are giving better performance for extra risk taken by the investors.

\subsection{Beta Value}

Beta measures the systematic risk and explains the volatility of the security return therewith of the market return.

If beta values are but one, it means funds risk is a smaller amount than the market risk; if it's one, it means the fund's risk is same as that of the market risk and if the beta is quite one, the risk of the funds is larger than that of the market.

All the funds, by and enormous, have the beta values on an average approximately adequate to 0.99 , implying lower volatility within the returns of the ETFs and Index Funds than the underlying Index volatility. Risk of ETFs also as Index Funds is found to be less than market risk. 


\subsection{Alpha}

Jensen's alpha was wont to measure the surplus returns of a fund over that of its underlying index. The excess of a fund was regressed against the returns of its underlying index.

The higher the alpha, the more the portfolio is in a position to earn above the anticipated level. Within the ETFs and Index Funds Kotak Sensex ETF giving the highest alpha which suggests this ETF is in a position to perform much above the anticipated level. Overall, ETFs have higher alpha values than index funds.

\section{SUGGESTIONS AND CONCLUSIONS}

In this study, ten funds were selected that tracked CNX Nifty and S \& P BSE SENSEX for which risk and return were analyzed on the basis of data extracted from secondary sources. The analysis revealed that in terms of annual returns ETFs provided the highest return in all the five years, even when in the 2015 market was falling ETFs managed to perform better than Index Funds. Further, the risk was analyzed using standard deviation, Sharpe ratio, Beta, Alpha, and R squared values. Through analysis, it was discovered that ETFs are riskier than Index Funds thus are generating better returns. The value of alpha for all the funds is positive which is a noteworthy point as it shows that all the funds are generating excess return over market return. Beta value shows lower volatility amongfunds.

\section{LIMITATIONS OF THE STUDY}

The major limitation of this study is that the sample size has been substantially reduced. The results of this study could vary if the size of the sample is increased. Thus, there is a great scope for further study.

\section{REFERENCES}

1. D. V. K. M. a. D. K. S. Prasad, "Performance of Exchange Traded Funds. A comparative Analysis of Index ETF's and Index funds in India," AMET International Journal of Management, 2016.

2. A. \&. K. R. Gaba, "Exchange Traded Funds Vs Index Funds: Comparative Performance Analysis," Effulugence-A management Journal, 2006.

3. M. B. DR(MRS) Prasanth Athma, "Performance of equity Exchange Traded Funds in India: An Analysis," International Journal of Business and Management Invention(IJBMI), 2017.

4. B. C. Kurian, "Exchange Traded Funds in India," International Journal of Scientific Engineering and Research, 2017.

5. S. Narend, "Performance of ETFs and Index Funds: A Comparative analysis," NSE, 2014.

6. Rompotis.G, "ETFS Vs Mutual Funds: Evidence of the Greek Market," South-Eastern Europe Journal of Economis, 2011.

7. A. A, "Conventional mutual index funds versus exchange-traded funds," Journal of Financial Markets, 2011.

8. l. Kostovetsky, "index Mutual Funds and Exchange Traded Funds," Journal of Portfolio Management, 2003.

9. J. P.Bhuvaneshwari, "performance Analysis of Exchange Traded Funds in India," Smart Journal of Business, 2009. 